\section{Light attracted butterflies: a review from the Indian sub-region with an inventory from West Bengal, India}

\section{Soumyajit Chowdhury ${ }^{1} \&$ Rahi Soren ${ }^{2}$}

${ }^{1}$ School of Oceanographic Studies, Jadavpur University, 32 Raja S. C. Mullick Road, Kolkata, West Bengal 700032, India ${ }^{2}$ Ecological Research Unit, Department of Zoology, University of Calcutta, 35 Ballygunge Circular Road, Kolkata, West Bengal 700019, India

Email: ${ }^{1}$ wildlifesc@gmail.com (corresponding author),

${ }^{2}$ rahisoren@gmail.com

Some of the nocturnal Lepidoptera, mostly moths (Heterocera) are negatively heliotropic but positively phototactic, being impelled by an irresistible attraction to a bright lamp (Willey 1867). Phototaxis (attraction to artificial lights) has, however, been explained to be somewhat different from heliotropism (attraction to natural/sunlight) by Willey (1867). On the basis of exploiting natural light/sunlight, butterflies (Rhopalocera) can be categorized in two broad groups, viz., (i) the diurnal ones, with day flying habit and retiring at dusk, and (ii) the crepuscular ones, with a flying habit at dusk and even low-light conditions. For the night, they usually take shelter among bushes and trees. However, several observations regarding their occasional response to artificial light have been reported from both old and new worlds.

Date of publication (online): 26 June 2011

Date of publication (print): 26 June 2011

ISSN $0974-7907$ (online) | 0974-7893 (print)

Editor: Peter Smetacek

Manuscript details:

Ms \# 02476

Received 03 June 2010

Final revised received 02 May 2011

Finally accepted 13 May 2011

Citation: Chowdhury, S. \& R. Soren (2011). Light attracted butterflies: review from the Indian sub-region with an inventory from West Bengal, India. Journal of Threatened Taxa 3(6): 1868-1871.

Copyright: (c) Soumyajit Chowdhury \& Rahi Soren2011. Creative Commons Attribution 3.0 Unported License. JoTT allows unrestricted use of this article in any medium for non-profit purposes, reproduction and distribution by providing adequate credit to the authors and the source of publication

Acknowledgements: We are grateful to the Bombay Natural History Society for making an access to the necessary articles related to the present context by bringing out the DVD on 100 volumes of the Journal of the Bombay Natural History Society.

OPEN ACCESS | FREE DOWNLOAD
The occasional phenomenon regarding attraction of butterflies to artificial lights in the Indian sub-

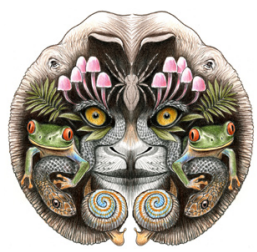
region have been reported in the literature. The first report was published by J.I. Alfrey in a paper by Best (1951) concerning the sighting of Lime Butterfly (Papilio demoleus demoleus Linnaeus) attracted to "Kitson Oil Lamps" at night at the railways station in Jhansi (southern Uttar Pradesh State, India) during a migration. Later, more detailed observations were published by Usman (1956), Donahue (1962), Shull (1964), Shull \& Nadkerny (1967), Nadkerny \& Shull (1968), Sharma \& Chaturvedi (1999), Nair (2001) and Sharma \& Chaturvedi (2005).

The present article deals with a review on the earlier observations on light-attracted butterflies in the Indian subcontinent with additions of four new species responding to the same from West Bengal. The primary objective is thus to elaborate the diversity and seasonal inclination of light-attracted butterflies in the Indian sub-region along with a possible explanation for such an unusual phenomenon.

Materials and Methods: The primary review work regarding the cases of light-attracted butterflies in the Indian sub-region from the period between 1951 and 2005 was accomplished through literature surveys.

Both inadvertent observations as well as designed experiments were undertaken during that period. However, the records for light-attracted butterflies in the urban (Kolkata) and forested regions (Samsing and Buxa of the Dooars) of West Bengal are new from this region and resulted from incidental observations during the period 2008 to 2009 . No intentional lighttraps were designed in those places for attracting butterflies at night

Results: The light-attracted butterflies recorded by the earlier authors from 1951-2005 revealed 27 species belonging to five families. Table 1 shows a list of the species, along with the place; season of observation and the type of artificial light source to which they were attracted. The observations by the present authors (2008-2009) report six butterfly species that were attracted to light at night from Kolkata and Dooars (Samsing and Buxa) regions of southern and northern West Bengal, India. Four species reported here, viz. Papilio polytes Linnaeus, Tanaecia lepidea Butler, Neptis sp. and Pelopidas 
Table 1. A summary of the published data on butterfly species attracted to artificial light sources (1951-2005).

\begin{tabular}{|c|c|c|c|c|}
\hline Species & Observer & Place & Season (Year) & Artificial Light Source \\
\hline \multicolumn{5}{|l|}{ Papilionidae } \\
\hline $\begin{array}{l}\text { 1. Lime Butterfly } \\
\text { (Papilio demoleus demoleus Linn.) }\end{array}$ & $\begin{array}{l}\text { J.I. Alfrey (in Best } \\
\text { 1951) }\end{array}$ & $\begin{array}{l}\text { Jhansi (southern Uttar Pradesh, } \\
\text { northerncentral India) }\end{array}$ & Data Deficient & Kitson oil lamps \\
\hline $\begin{array}{l}\text { 2. Tailed Jay } \\
\text { (Graphium agamemnon Linn.) }\end{array}$ & $\begin{array}{l}\text { Sharma \& } \\
\text { Chaturvedi (2005) }\end{array}$ & Pune (Maharashtra, western India) & April (2002) & Neon tube \\
\hline \multicolumn{5}{|l|}{ Pieridae } \\
\hline $\begin{array}{l}\text { 3. Common Emigrant } \\
\text { (Catopsilia crocale Cramer) }\end{array}$ & $\begin{array}{l}\text { Shull \& Nadkerny } \\
\text { (1967) }\end{array}$ & Surat Dangs (Gujarat, western India) & $\begin{array}{l}\text { Mid June - Mid } \\
\text { Oct (1961) }\end{array}$ & $\begin{array}{l}\text { Mercury vapour } \\
\text { lamp }\end{array}$ \\
\hline $\begin{array}{l}\text { 4. Small Grass Yellow } \\
\text { (Eurema brigitta Cramer) }\end{array}$ & $\begin{array}{l}\text { Shull \& Nadkerny } \\
\text { (1967) }\end{array}$ & Surat Dangs (Gujarat, western India) & $\begin{array}{l}\text { Mid June - Mid } \\
\text { Oct (1961) }\end{array}$ & Mercury vapour lamp \\
\hline $\begin{array}{l}\text { 5. Common Grass Yellow } \\
\text { (Eurema hecabe Linn.) }\end{array}$ & $\begin{array}{l}\text { Shull \& Nadkerny } \\
\text { (1967) }\end{array}$ & Surat Dangs (Gujarat, western India) & $\begin{array}{l}\text { Mid June - Mid } \\
\text { Oct (1961) }\end{array}$ & Mercury vapour lamp \\
\hline $\begin{array}{l}\text { 6. Spotless Grass Yellow } \\
\text { (Eurema laeta Boisd.) }\end{array}$ & $\begin{array}{l}\text { Shull \& Nadkerny } \\
\text { (1967) }\end{array}$ & Surat Dangs (Gujarat, western India) & $\begin{array}{l}\text { Mid June - Mid } \\
\text { Oct (1961) }\end{array}$ & Mercury vapour lamp \\
\hline $\begin{array}{l}\text { 7. Common Gull } \\
\text { (Cepora nerissa Fab.) }\end{array}$ & $\begin{array}{l}\text { Shull \& Nadkerny } \\
\text { (1967) }\end{array}$ & Surat Dangs (Gujarat, western India) & $\begin{array}{l}\text { Mid June - Mid } \\
\text { Oct (1961) }\end{array}$ & Mercury vapour lamp \\
\hline $\begin{array}{l}\text { 8. Pioneer } \\
\text { (Anaphaeis aurota Fab.) }\end{array}$ & $\begin{array}{l}\text { Nadkerny \& Shull } \\
\text { (1968) }\end{array}$ & Dangs (S. Gujarat, western India) & $\begin{array}{l}\text { Aug - Sep } \\
(1961)\end{array}$ & Mercury vapour lamp \\
\hline $\begin{array}{l}\text { 9. Small Salmon Arab } \\
\text { (Colotis calais Cramer) }\end{array}$ & $\begin{array}{l}\text { Nadkerny and } \\
\text { Shull (1968) }\end{array}$ & Dangs (S. Gujarat, western India) & $\begin{array}{l}\text { Aug - Sep } \\
(1961)\end{array}$ & Mercury vapour lamp \\
\hline \multicolumn{5}{|l|}{ Nymphalidae } \\
\hline $\begin{array}{l}\text { 10. Striped Tiger } \\
\text { (Danaus chrysippus Linn.) }\end{array}$ & Donahue (1962) & New Delhi ( northerncentral India) & October (1961) & $\begin{array}{l}150 \mathrm{~W} \text { porch light, } \\
60 \mathrm{~W} \text { tungsten bulb }\end{array}$ \\
\hline $\begin{array}{l}\text { 11. Black Rajah } \\
\text { (Charaxes solon Fab.) }\end{array}$ & $\begin{array}{l}\text { Sharma \& } \\
\text { Chaturvedi (1999) }\end{array}$ & $\begin{array}{l}\text { Tadoba National Park (Maharashtra, } \\
\text { western India) }\end{array}$ & $\begin{array}{l}\text { December } \\
(1996)\end{array}$ & Data deficient \\
\hline $\begin{array}{l}\text { 12. Common Evening Brown } \\
\text { (Melanitis leda Linn.) }\end{array}$ & Donahue (1962) & New Delhi (northerncentral India) & August (1961) & Porch light \\
\hline $\begin{array}{l}\text { 13. Blue Pansy } \\
\text { (Junonia orithya Linn.) }\end{array}$ & Donahue (1962) & New Delhi (northerncentral India) & $\begin{array}{l}\text { November } \\
(1961)\end{array}$ & Porch light \\
\hline $\begin{array}{l}\text { 14. Nigger } \\
\text { (Orsotrioena medus Fab.) }\end{array}$ & Nair (2001) & $\begin{array}{l}\text { Aralam Wildlife Sanctuary } \\
\text { (Kerala, southern India) }\end{array}$ & February (2001) & Neon tube light \\
\hline $\begin{array}{l}\text { 15. Common Castor } \\
\text { (Ariadne merione merione Cramer) }\end{array}$ & $\begin{array}{l}\text { Shull \& Nadkerny } \\
\text { (1967) }\end{array}$ & Surat Dangs (Gujarat, western India) & $\begin{array}{l}\text { Mid June - Mid } \\
\text { Oct (1961) }\end{array}$ & Mercury vapour lamp \\
\hline $\begin{array}{l}\text { 16. Common Baron } \\
\text { (Euthalia aconthea Cramer) }\end{array}$ & $\begin{array}{l}\text { Shull \& Nadkerny } \\
\text { (1967) }\end{array}$ & Surat Dangs (Gujarat, western India) & $\begin{array}{l}\text { Mid June - Mid } \\
\text { Oct (1961) }\end{array}$ & Mercury vapour lamp \\
\hline $\begin{array}{l}\text { 17. Yellow Pansy } \\
\text { (Junonia hierta hierta Fab.) }\end{array}$ & $\begin{array}{l}\text { Shull \& Nadkerny } \\
(1967)\end{array}$ & Surat Dangs (Gujarat, western India) & $\begin{array}{l}\text { Mid June - Mid } \\
\text { Oct (1961) }\end{array}$ & Mercury vapour lamp \\
\hline $\begin{array}{l}\text { 18. Painted Lady } \\
\text { (Vanessa cardui Linn.) }\end{array}$ & $\begin{array}{l}\text { Shull \& Nadkerny } \\
\text { (1967) }\end{array}$ & Surat Dangs (Gujarat, western India) & $\begin{array}{l}\text { Mid June - Mid } \\
\text { Oct (1961) }\end{array}$ & Mercury vapour lamp \\
\hline \multicolumn{5}{|l|}{ Lycaenidae } \\
\hline $\begin{array}{l}\text { 19. Red Pierrot } \\
\text { (Talicada nyseus Guérin-Menéville) }\end{array}$ & Usman (1956) & $\begin{array}{l}\text { Bangalore (Karnataka, southern } \\
\text { India) }\end{array}$ & $\begin{array}{l}\text { Mar - May } \\
(1955)\end{array}$ & $\begin{array}{l}\text { Tungsten lamp } \\
(25 \mathrm{~W})\end{array}$ \\
\hline $\begin{array}{l}\text { 20. Gram Blue } \\
\text { (Euchrysops cnejus Fab.) }\end{array}$ & Nair (2001) & $\begin{array}{l}\text { Aralam Wildlife Sanctuary } \\
\text { (Kerala, southern India) }\end{array}$ & February (2001) & CFL lamp \\
\hline $\begin{array}{l}\text { 21. Lime Blue } \\
\text { (Chilades lajus Stoll) }\end{array}$ & $\begin{array}{l}\text { Sharma \& } \\
\text { Chaturvedi (2005) }\end{array}$ & $\begin{array}{l}\text { Sanjay Gandhi National Park } \\
\text { (Maharashtra, western India) }\end{array}$ & $\begin{array}{l}\text { September } \\
\text { (2001) }\end{array}$ & Neon tube light \\
\hline $\begin{array}{l}\text { 22. Tiny Grass Blue } \\
\text { (Zizula hylax Fab.) }\end{array}$ & Nair (2001) & $\begin{array}{l}\text { Aralam Wildlife Sanctuary } \\
\text { (Kerala, southern India) }\end{array}$ & February (2001) & CFL lamp \\
\hline $\begin{array}{l}\text { 23. Dark Grass Blue } \\
\text { (Zizeeria karsandra Moore) }\end{array}$ & $\begin{array}{l}\text { Shull \& Nadkerny } \\
\text { (1967) }\end{array}$ & Surat Dangs (Gujarat, western India) & $\begin{array}{l}\text { Mid June - Mid } \\
\text { Oct (1961) }\end{array}$ & Mercury vapour lamp \\
\hline $\begin{array}{l}\text { 24. Powdery Green Sapphire } \\
\text { (Heliophorus tamu tamu Koll.) }\end{array}$ & $\begin{array}{l}\text { Nadkerny \& Shull } \\
(1968)\end{array}$ & Dangs (S. Gujarat, western India) & $\begin{array}{l}\text { Aug - Sep } \\
(1961)\end{array}$ & Mercury vapour lamp \\
\hline \multicolumn{5}{|l|}{ Hesperiidae } \\
\hline $\begin{array}{l}\text { 25. Common Redeye } \\
\text { (Gangara thyrsis Fab.) }\end{array}$ & Best (1956) & Bombay (Maharashtra, western India) & $\begin{array}{l}\text { Feb - June } \\
(1956)\end{array}$ & Lamp \\
\hline $\begin{array}{l}\text { 26. Common Banded Awl } \\
\text { (Hasora chromus Cramer) }\end{array}$ & $\begin{array}{l}\text { Shull \& Nadkerny } \\
\text { (1967) }\end{array}$ & Surat Dangs (Gujarat, western India) & $\begin{array}{l}\text { Mid June - Mid } \\
\text { Oct (1961) }\end{array}$ & Mercury vapour lamp \\
\hline $\begin{array}{l}\text { 27. Conjoined Swift (Pelopidas } \\
\text { conjuncta Herrich-Schaeffer) }\end{array}$ & $\begin{array}{l}\text { Shull \& Nadkerny } \\
\text { (1967) }\end{array}$ & Surat Dangs (Gujarat, western India) & $\begin{array}{l}\text { Mid June - Mid } \\
\text { Oct (1961) }\end{array}$ & Mercury vapour lamp \\
\hline
\end{tabular}


Table 2. A summary of the butterfly species attracted to artificial light sources as recorded by present authors (2008-2009)

\begin{tabular}{|c|c|c|c|}
\hline Species & Place & Season (Year) & Artificial light source \\
\hline \multicolumn{4}{|l|}{ Papilionidae } \\
\hline $\begin{array}{l}\text { 1. Common Mormon } \\
\text { (Papilio polytes Linn.) }\end{array}$ & Kolkata (West Bengal, eastern India) & August (2009) & Neon tube light \\
\hline \multicolumn{4}{|l|}{ Nymphalidae } \\
\hline $\begin{array}{l}\text { 2.Grey Count } \\
\text { (Tanaecia lepidea Butler) }\end{array}$ & Samsing (West Bengal, eastern India) & June (2009) & Hazack lamp \\
\hline $\begin{array}{l}\text { 3. Sailer species } \\
\text { (Neptis Fabricius) }\end{array}$ & Samsing (West Bengal, eastern India) & June (2009) & Hazack lamp \\
\hline $\begin{array}{l}\text { 4. Common Evening Brown } \\
\text { (Melanitis leda Linn.) }\end{array}$ & Kolkata (West Bengal, eastern India) & $\begin{array}{l}\text { October, November } \\
(2009)\end{array}$ & Neon tube light \\
\hline \multicolumn{4}{|l|}{ Lycaenidae } \\
\hline $\begin{array}{l}\text { 5. Lime Blue } \\
\text { (Chilades lajus Stoll.) }\end{array}$ & $\begin{array}{l}\text { Buxa Tiger Reserve (West Bengal, eastern } \\
\text { India) }\end{array}$ & May (2008) & Neon tube light \\
\hline \multicolumn{4}{|l|}{ Hesperiidae } \\
\hline $\begin{array}{l}\text { 6. Small Branded Swift } \\
\text { (Pelopidas mathias Fab.) }\end{array}$ & Kolkata (West Bengal, eastern India) & October (2009) & Neon tube light \\
\hline
\end{tabular}

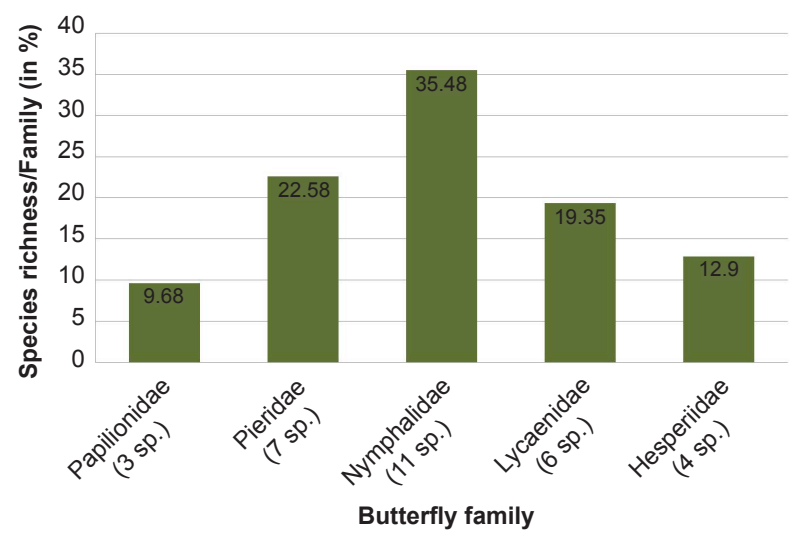

Figure 1. A graphical representation showing the relative richness for light-attracted butterfly species in terms of their families (1951-2009).

mathias Fab. are additions to the known butterflies subject to this phenomenon in India (Table 1), while Chilades lajus Stoll. and Melanitis leda Linn have also been reported earlier by Sharma \& Chaturvedi (2005) from Maharashtra and by Donahue (1962) from Uttar Pradesh respectively. All the species were observed as single individuals during a single light-attraction event. No mass attractions were thus observed for the species in West Bengal. The observations by the present authors are detailed in Table 2 .

A total of 31 species of butterfly resulting from the past and present observations showed occasional response to a variety of artificial lights in different parts of the Indian region. Among these, nymphalids $(35.48 \%)$ outnumber the rest, followed by pierids

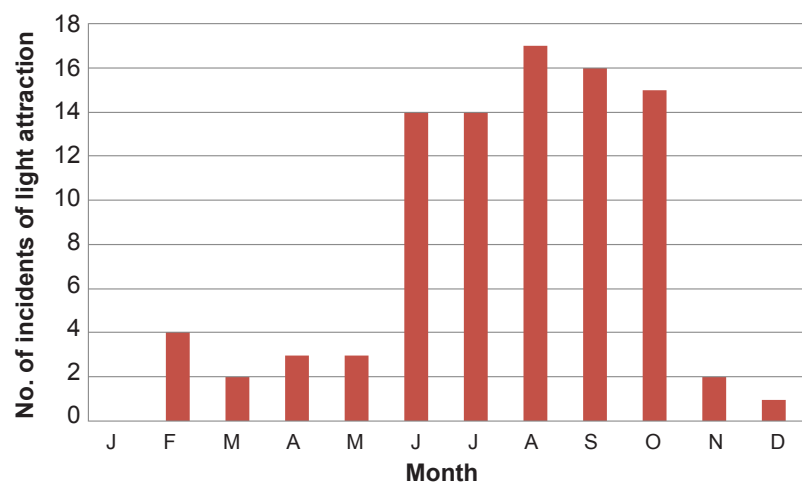

Figure 2. Incidences of butterfly species attracted to light in accordance with months (1951-2009), showing maximum records during the monsoon (Jun-Oct).

(22.58\%), lycaenids (19.35\%), hesperiids (12.9\%) and papilionids (9.68\%) (Fig. 1). The observations (Tables $1 \& 2$ ) also reveal a seasonal inclination for such a phenomenon, as the maximum incidents were recorded during the monsoon months (June-October) in the Indian sub-region (Fig. 2).

Discussion and Conclusion: Crepuscular species, like Melanitis leda, are more active in the dark than the sun-loving, diurnal species, and thus are attracted more frequently to artificial lights (Donahue 1962).

The phenomenon of light attraction among butterflies has been found to be inclined more in the monsoon season (June-October) in the Indian subregion. Heavy downpours during the monsoon months may disrupt the night-time shelters of some butterfly 
individuals, inducing them to move from their former preferred site to a new one. In the absence of optimum light, they fail to do so using visual cues. In that case, a source of artificial light with an intensity enough to stimulate them to get attracted may serve the purpose of utilizing their visual potency to search for a safe shelter. Throne (1961) also suggested that a butterfly may fly at light if it is disturbed at night and is near the light in the first place. Heitzman (1965) was certain that a large percentage of the specimens collected at light were startled from their resting places in nearby trees or bushes by the collector or some larger insects attracted towards light. Donahue (1962), however, noted that the butterfly numbers were greatest during the monsoon months, particularly in arid areas (like New Delhi, where his observations were made) when there is an abundance of food. He therefore pointed out the coincidence of the population peak with the rainy season, and either one or both these factors might influence the activity of certain species at light. $\mathrm{He}$ also indicated the probable effect of temperature upon the nocturnal activity of the observed species, since most of his observations were in the monsoon months, with no record of any species in winter.

Furthermore, as in most cases of butterfly attraction towards a light source near their resting places, occasional incidents were reported where specimens were drawn from a considerable distance (Heitzman 1965). Donahue (1962) also argued that in some instances the butterfly would have to expend some effort to reach that light. Moreover, approaching that source, many of them tend to settle near the light. As light is an important cue that attracts insects to sources of heat (Schowalter 2006), the warmth obtained on getting nearer the light may also help in thermoregulation.

Further observations and experimentations on Indian butterflies being attracted to light at night may provide a less speculative explanation of phototactic and nocturnal behaviour.

\section{REFERENCES}

Best, A.E.G. (1951). The Butterflies of Bombay and Salsette. Journal of the Bombay Natural History Society 50(2): 331339.

Best, A.E.G. (1956). Further Notes and Additions to the list of Butterflies from Bombay and Salsette. Journal of the Bombay Natural History Society 54(1): 215-216.

Donahue, J.P. (1962). Observations and records of butterflies attracted to light in India. Journal of the Lepidopterists' Society 16(12): 131-135.

Heitzman, R. (1965). More observations on the attraction of diurnal lepidoptera to light. Journal of the Lepidopterists' Society 19(3): 179-180.

Nadkerny, N.T. \& E.M. Shull (1968). Insects attracted to light in the dangs, south Gujarat. Journal of the Bombay Natural History Society 65(3): 800.

Nair, V.P. (2001). Butterflies attracted to light at Aralam Wildlife Sanctuary, Kerala. Zoos' Print Journal 16(12): 670.

Schowalter, T.D. (2006). Insect Ecology: An Ecosystem Approach $-2^{\text {nd }}$ Edition. Academic Press Publications, USA, $574 \mathrm{pp}$.

Sharma, R.M. \& N. Chaturvedi (2005). Additions to the light attracted butterflies. Journal of the Bombay Natural History Society 102(1): 129.

Sharma, R.M. \& N. Chaturvedi (1999). Black Rajah Charaxes fabius attracted to light at Tadoba National Park. Journal of the Bombay Natural History Society 96(1): 168-169.

Shull, E.M. (1964). Butterflies attracted to light in Gujarat State, India. Journal of the Lepidoperists' Society 18(30): 159-163.

Shull, E.M. \& N.T. Nadkerny (1967). Insects attracted to mercury vapour lamp in the Surat Dangs, Gujarat State. Journal of the Bombay Natural History Society 64 (2): 256-266.

Throne, A.L. (1961). Lycaenopsis pseudargiolus in light trap. Journal of Lepidopterists' Society 14: 242.

Usman, S. (1956). Some insects attracted to light-Part III. Journal of the Bombay Natural History Society 53(3): 482-484.

Welling, E.C. (1963). Rhopalocera attracted by ulraviolet light in Central America. Journal of Lepidopterists' Society 17(1): 37-38.

Willey, A. (1867). Convergence in Evolution. New York, E. P. Dutton \& Co, xiii+177pp. 